\title{
A Study on Brushless DC Motor for Air Fan Module of Fuel Cell Power Pack
}

\author{
J. M. Seo ${ }^{1,2}$, J. H. Kim ${ }^{1}$, I. S. Jung ${ }^{1}$ and H. K. Jung ${ }^{2}$ \\ ${ }^{1}$ Intelligent Mechatronics Research Centre, Korea Electronics Technology Institute \\ Wonmi-gu, Puchon, 420-140 Gyeonggi-do (Korea) \\ Phone/Fax number:+82 32 6212852/6212855, e-mail: sjm@keti.re.kr, kimjh@keti.re.kr, isjung@keti.re.kr \\ ${ }^{2}$ Department of Electrical Engineering and Computer Science \\ Seoul National University, Seoul (Korea) \\ Phone/Fax number:+82 2 8807241/8715974, e-mail: hkjung@snu.ac.kr
}

\begin{abstract}
This paper presents design of brushless DC (BLDC) motor which is applied in air fan module for fuel cell power pack. Developed motor is outer rotor type BLDC motor, high efficiency and low cost are main targets to achieve in design process. Manufactured motor is combined with blade fan, and air flow and pressure with respect to the various load conditions are measured. From the simulated and measured results, we verify the application possibility as air fan module for power pack.
\end{abstract}

\section{Key words}

Fuel cell power pack, Air fan module, Brushless DC motor

\section{Introduction}

Increase of high power portable devices attracts abundant attention to high-capacity movable power supply. Various attempts are continuing to increase the energy density of secondary battery, however, satisfactory results are not presented till now. Fuel cell system is one of the alternative technologies and the application fields are extensive, for instance, transportations, power plants, and portable military devices [1-2]. The main parts of the fuel cell systems are stack and balance of plant (BOP). BOP increases the operating performance and durability of the stack by controlling pressure, temperature, and humidity of fuel or air. BOP consists of fuel and air supply device, power converter and controller, heat exchanger, sensors, reformer. This paper presents BLDC motor of air fan module for cooling and air supply. Considering driving and installation conditions, the specifications of motor are determined and manufactured motor are assembled to fan module to estimate performance characteristics.

\section{Design and simulation}

The proposed motor is 3 phase BLDC type with 6 pole and 9 slots. Conventional single or 2 phase motors for fan module have relatively great speed changes according to the load variations, they are unfavourable in BOP systems requiring wide load ranges. In addition, 3 phase motors have low noise and vibration characteristics due to low torque ripple, and high efficiency is expected. Ring type rubber magnet is applied and sensorless driving scheme is chosen. The specific design parameters of the proposed motor are shown in Table 1.

Fig. 1 shows magnetic flux density of rotor and stator core at rated driving condition. The maximum flux density of the teeth and yoke are 1.21 and $1.26 \mathrm{~T}$, respectively. The cogging torque and back EMF are $1.1 \mathrm{mNm} 0$-pk and 0.74V0-pk @1,000rpm, respectively. The cogging torque is about $10 \%$ of rated torque and no load speed and torque constant can be estimated using the calculated EMF value. Fig. 1(d) shows rated torque wave when input voltage of $12 \mathrm{~V}$ is applied. In rotational speed of $6,500 \mathrm{rpm}$, rated torque of $13.8 \mathrm{mNm}$ is induced.

Table I. Specific parameters of designed motor

\begin{tabular}{|c|c|c|}
\hline parameters & value & unit \\
\hline pole/slot & $6 / 9$ & \\
\hline rotor diameter & 35 & $\mathrm{~mm}$ \\
\hline stator diameter & 24.5 & $\mathrm{~mm}$ \\
\hline active length & 13 & $\mathrm{~mm}$ \\
\hline air gap & 0.5 & $\mathrm{~mm}$ \\
\hline permanent magnet & rubber & \\
\hline coil diameter & 0.35 & $\mathrm{~mm}$ \\
\hline turn number per phase & 90 & \\
\hline
\end{tabular}

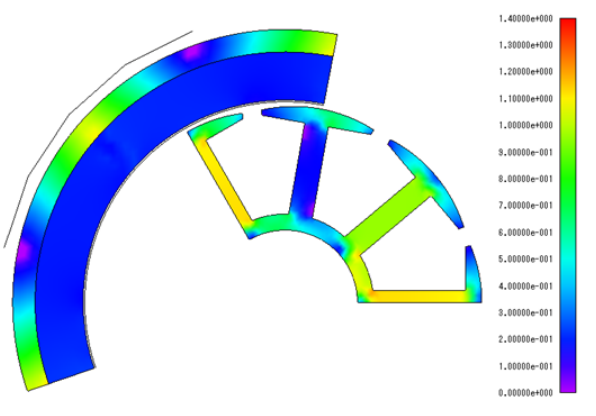

(a) 


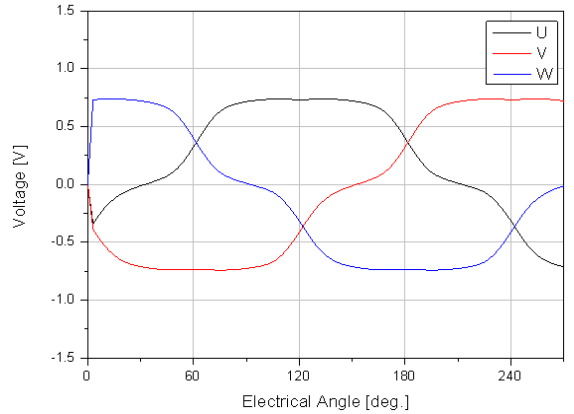

(b)

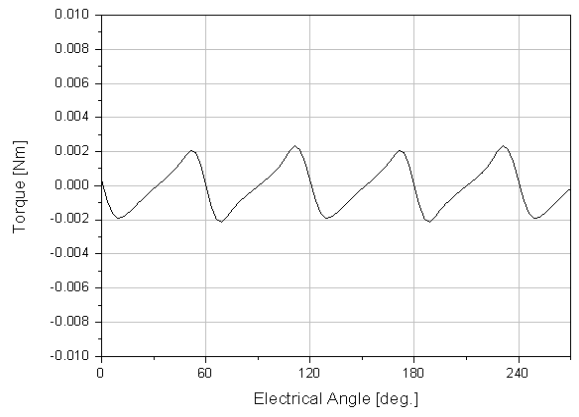

(c)

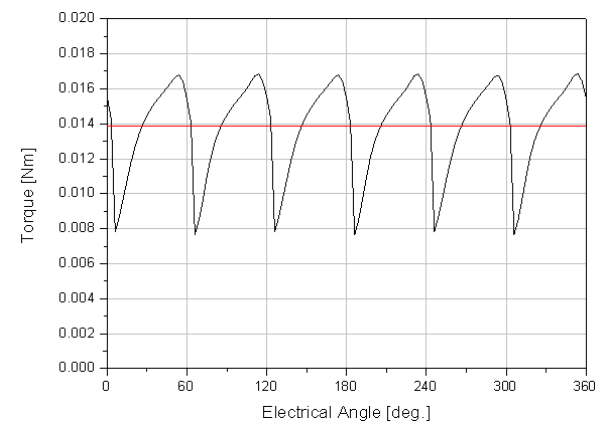

(d)

Fig. 1. Simulated results of the proposed motor. Magnetic flux density(a), back EMF(b), cogging torque(C), rated torque(d).

\section{Manufacturing and test}

Fig. 2 shows manufactured motor based on above design parameters. PCB board for connection of phase coils is located between stator core and lower base yoke, and ring type magnet is boned inside the rotor core. The measured EMF wave of the manufactured motor is shown in Fig. 3. A reasonable agreement is seen to be achieved in value and shape comparing with the simulated result in Fig. 1. Through the results we can confirm that the applied material characteristics of permanent magnet and core, and winding specification are reflected well in manufacturing process.
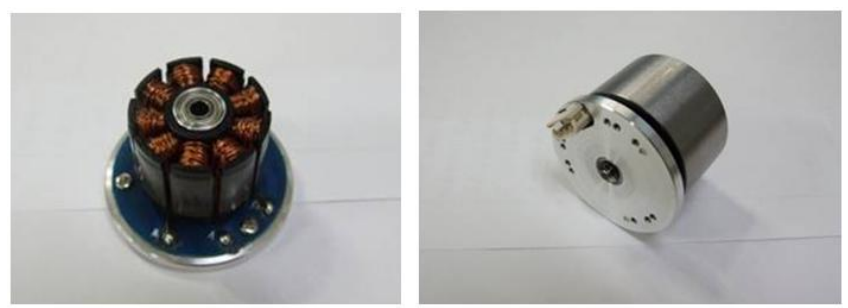

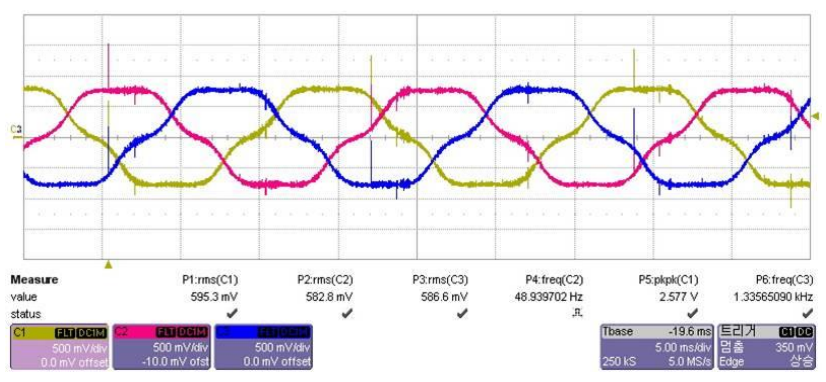

Fig. 3. Measured EMF@ 1,000rpm

Fig. 4 shows input and output characteristics of the proposed motor with respect to the load variations. The measurement equipment consists of a DC power supply, dynamometer, powermeter, and a laptop computer for display and load control. When rated input voltage of $12 \mathrm{~V}$ is applied, the maximum efficiency of $79.1 \%$ and the rotational speed of $6,500 \mathrm{rpm}$ are estimated within the rated load range from 10 to $12 \mathrm{mNm}$. Fig. 5 shows phase current wave of motor when load torque of $12 \mathrm{mNm}$ is applied in which we confirm favourable switching of inverter is developed. The input current value is $808 \mathrm{~mA}$ and stable driving can be expected considering current density. Fig. 6 shows the designed fan blade and the completed blower module. The fan blade is assembled to the rotor core of the motor and the stator of the motor is united to module case. Fig. 7 shows test bench for air flow and pressure. The maximum air flow is about $2 \mathrm{CMM}$ and the maximum efficiency of $21.5 \%$ is estimated at the air flow of 1.6CMM as shown in Fig. 8.

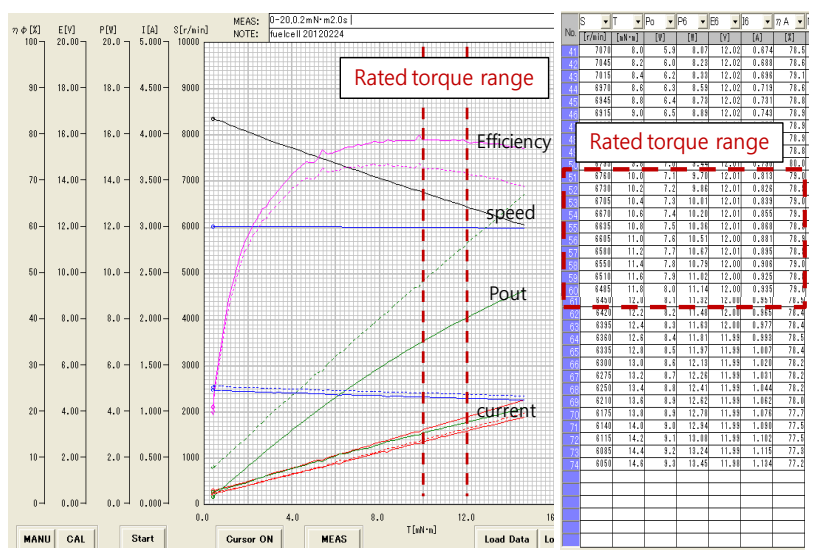

Fig. 4. Input and output characteristics with respect to load variations

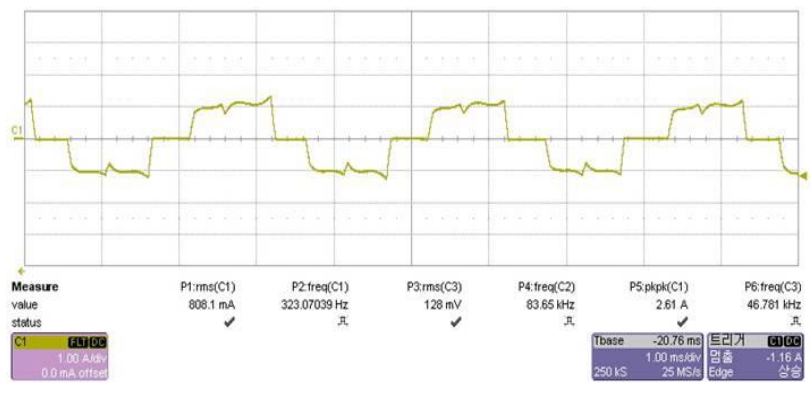

Fig. 5. Input current at rated load torque

Fig. 2. Manufacture motor 

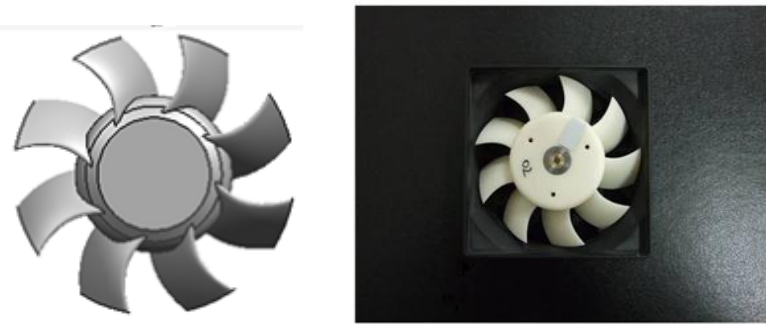

Fig. 6. Designed blade and assembled air fan module

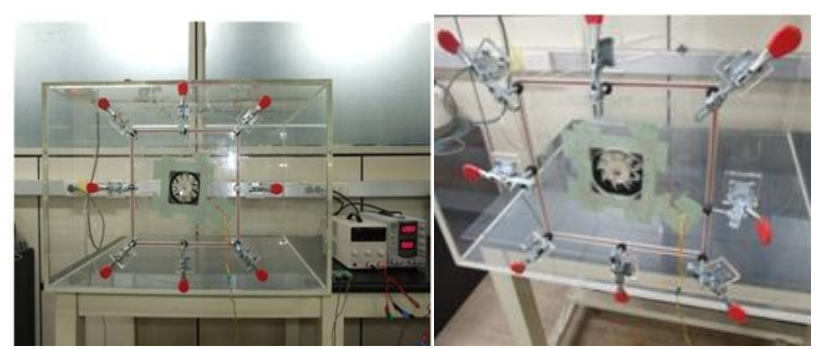

Fig. 7. Test bench for air flow and pressure

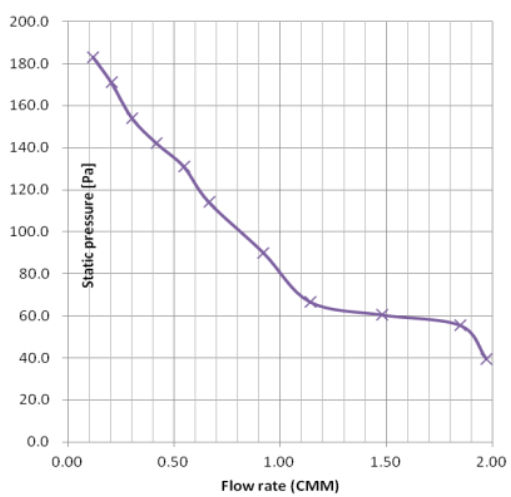

(a)

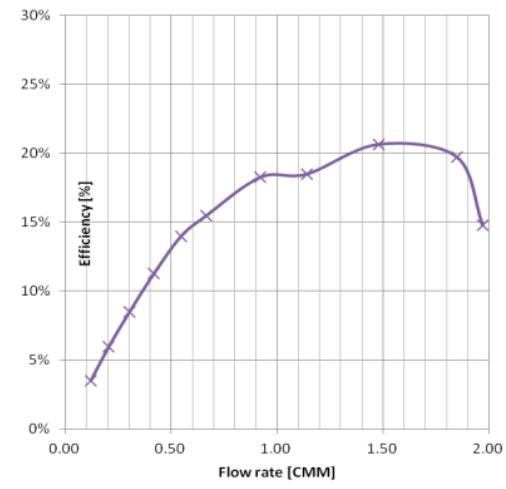

(b)

Fig. 8. Static pressure (a) and efficiency (b) with respect to the air flow variations

\section{Conclusion}

This paper presents design of brushless DC motor of the air fan module for fuel cell power pack of $150 \mathrm{~W}$. Developed motor has outer rotor with rubber magnet for low cost. The rated power is $8 \mathrm{~W}$ and the maximum efficiency is gained within rated driving range. The manufactured motor is combined with fan blade and tested for air flow, pressure, and efficiency. In extensive paper, we will present more specific design methods and discussion supporting above results

\section{References}

[1] N. Kato and K. Kurozumi, "'Hybrid power supply system composed of photovoltaic and fuel-cell systems,"” in Proc. INTELEC'01, pp.631-635, 2001

[2] M. N. Eskander and T. F. El-Shatter, ""Energy flow and management of a hybrid wind/PV/fuel cell generation system,"” in Proc. IEEE PESC'02, pp.347-353, 2002, 